\title{
The Architects' Small House Service Bureau and the American Institute of Architects
}

\author{
Lisa M. Tucker, PhD \\ Virginia Polytechnic Institute and State University, Blacksburg, Virginia
}

\begin{abstract}
A group of Minnesota architects created the ASHSB in 1914 to provide a solution for the shortage of middle class housing in the U.S. By 1919, the bureau had offices throughout the U.S. and received the endorsement of both the American Institute of Architects and the Department of Commerce. During this time, the members of the Bureau produced hundreds of plan sets and monthly bulletins to assist homeowners with their housing choices. The monthly magazine The Small Home, in conjunction with the published plan books--Your Future Home and How to Plan, Finance, and Build Your Home--dispensed valuable information to potential homebuyers across the nation. To date, one master's thesis (Lisa Schrenk, University of Virginia 1990) and an article (Thomas Harvey, 1991) have been written about the ASHSB. Neither one discussed the relationship of this group with the AIA, a key endorsement agency.

This research involved extensive archival research at the AIA. Records from the early $20^{\text {th }}$ century were analyzed to determine the relationship between the AIA and the ASHSB in the early $20^{\text {th }}$ century. This relationship provides insight into the current lack of architectural involvement in single-family house design today.

The single most prevalent building type in the U.S. is the single-family house, yet architects are little involved in the design of most of them. Architects have the ability and training to create sustainable, affordable, and well-design single-family houses and yet they do not. This paper seeks to provide one explanation through the interpretation of the historic relationship of the AIA to the ASHSB.
\end{abstract}

Conference theme: Architectural design and the historical landscape

Keywords: architects, house, design, practice, history

\section{INTRODUCTION}

This paper examines the relationship between the Architects' Small House Service Bureau (ASHSB) and the American Institute of Architects (AIA) in the first quarter of the twentieth century. The historical positions adopted by members of the AIA during this period of time have had a significant impact on the current single-family house design market in the United States. Of examination of these issues underscores the need for architectural leadership in this arena both in the past and today.

\section{BACKGROUND}

\subsection{Architects Small House Service Bureau}

Following World War I, there was a critical shortage of housing in the U.S. In an effort to improve the design of the single-family house and capture a new market share for the professional designer, a group of four architects from Minneapolis, Minnesota started the Architects' Small House Service Bureau (ASHSB). To date only two publications have been written about the ASHSB. These include a master's thesis completed by
Lisa Schrenk at the University of Virginia in 1988 (parts of which were later published as a preface to the AIA reprint of an ASHSB plan book in 1992) and a short article in Landscape by Thomas Harvey in 1990.

\subsection{The American Institute of Architects}

The American Institution of Architects was the first iteration of an organization for architects. The Institution first met in 1836 and highlighted the lack of distinction between architects and builders-including both constituents--and was short-lived as a result of the internal and territorial conflicts. Charter members of the American Institution of Architects included William Strickland and Robert Mills as well as Thomas U. Walter and John Trautwine representing office-trained architects and Asher Benjamin, Minard Lefever, Alexander Parris and Ithiel Town, representing the master builder-turned architect contingent. The tensions between these two groups of men resulted in the organization's demise the following year. The goals of the Institution were to stress the scientific principles of architecture that made it a viable profession. They encouraged testing of architects in order to become a member (Woods 1999). 
In 1857, Upjohn's office hosted a pilot meeting for the second iteration of the professional organization, now renamed the American Institute of Architects (AIA). Most of the early members worked with or were associated with Upjohn's office. One notable exception, Richard Morris Hunt, received his training at the École des Beaux Arts. The two primary issues upon which the association focused were fees and competitions (Woods 1999). Both of these issues related to the realities of practicing architecture within the American capitalist system. Members attempted to create a framework whereby AIA members could receive compensation for competition entries that multiple government agencies solicited for free. In addition, the AIA members worked several years to establish a fee schedule to insure all members charged the same rates. (This was later repealed on the basis that the AIA was violating anti-trust law.)

Restructured in 1866, the AIA had dropped in popularity by the 1880's. Many architects viewed the organization as a gentlemen's club and as not very representative of all architects. Western architects such as Louis Sullivan, Dankmar Adler, Daniel Burnham, and John Root created their own association in response to the AIA. The Western Association of Architects, founded in 1884 and centered in Chicago, included 100 architects from fourteen mid-western states (Woods 1999). The Chicago-based group focused their attention on architectural design competitions (like the AIA) and, unlike the East coast architects, licensing. After a few years of vigorous conventions, the WAA merged with the AIA in 1889. Architects in the mid-west continued to pursue their licensing cause, however, and by 1897, the first licensing law was established in Illinois. By 1900, fifteen other states followed suit as licensing was replaced by registration laws. Despite this, the AIA resisted endorsing licensing for architects voting down measures to do so in both 1904 and 1906 (Woods 1999).

According to the AIA website, the AIA actually began when Richard Upjohn held a meeting of thirteen architects in his New York City office on February 23, 1857 (AIA website 2008). One of the first actions of the group was to restrict the use of the term "architect" which until this time was used by masons, carpenters, and builders. This move helped to limit membership in a way that the Institution had not done in the 1830s. At the first meeting, the original members created a list of sixteen additional architects to invite to join the Institute with the goal of elevating the profession (AIA website, 2008). By the late 1870s the organization had chapters in Chicago, Baltimore, San Francisco, Washington D.C., Philadelphia, and Boston. The first AIA convention was held in 1861. At this time, the AIA had thirty-two members and four associate members. Annual convention meeting proceedings were published until 1931 (AIA website, 2008). Membership grew gradually and with the advent of formalized education for architects in the university system that produced more architects, membership had grown to 11,500 by 1957 (AIA website 2008).
The Headquarters of the AIA moved to Washington D.C. in 1898 and operated out of the historic Octagon House (AIA website 2008). The current headquarters building is located behind the Octagon House, still owned by the Institute. The archives of the AIA are stored in the new headquarters building in Washington D.C.

\subsection{AIA endorsement of the ASHSB}

Initially, the small house issue was referred to simply as "housing." The first overt use of the terminology "small house problem" appears to occur in 1919 when the AIA voted to endorse the Architects Small House Service Bureau (ASHSB). From this point until well into the late 1930 s, ordinary single-family house design became known as "the small house problem." The terminology evoked the complexity of the situation that stemmed from a pronounced shortage of housing following World War I coupled with the shoddy construction across the nation that resulted from efforts to meet this need.

Shortly after this term was first used, the board of the AIA created the "House Committee" that later became the "Small House Committee" or the "Sub-Committee on the Small House." The Board of the AIA charged this committee with addressing the "small house problem" and with suggesting solutions. Until 1933, the Small House Committee's concerns were aligned with and to some degree addressed by the ASHSB. In 1934, however, the AIA voted to revoke its endorsement of the ASHSB. At this time the Small House Committee undertook to create its own group to provide plan services headed by the AIA. Specifically they addressed whether architects could and should be involved in single-family house design, and if so, how. Finally, near the time of the convention of April 1935, the Small House Committee was absorbed into the larger body of the Housing Committee. At first reports were given by the Small House Committee and the General Housing Committee (that focused more on large-scale housing). By the 1940s, the Housing Committee dropped its interest in the small house specifically and became more engaged in the issue of large-scale housing developments, particularly multifamily housing blocks.

For a brief time in the early twentieth century, the AIA chose to outsource the small house problem and aligned itself with a group of residential architects. Between 1919 and 1934 the AIA endorsed the Architects Small House Service Bureau. Although the endorsement was brief, this represents the only time in history when the AIA members voted in favor of a uniform solution to the single-family house design problem, as they perceived it, in the U.S.

The primary reasons many AIA members cited for revoking the AIA endorsement were as follows: (1) The ASHSB was in competition with AIA members and (2) The AIA could not control the quality of the ASHSB drawings and designs. Some members hoped they could recreate their own version of the ASHSB under AIA control and supervision. A leading proponent of small house design was Walter McCornack who chaired the Small House Committee during the 1930s. 
Following the Great Depression, the endorsement was ultimately revoked on the grounds that it amounted to direct competition with individual architects (Schrenk 1988). The ASHSB itself finally disbanded in 1942 having never recovered from the lack of continued AIA endorsement.

\subsection{Themes found in the documents}

A careful analysis of documents from the early twentieth century records of the AIA reveals the complexity of the issues facing the architecture profession with regard to the ordinary single-family house. These issues include the relationship of architects to builders, the prevalence of easy to obtain pattern books and house plan designs, the education, training and culture of architects and how this impacted their views about architecture, and the manner in which houses are constructed in the U.S.

The majority of the themes found in the AIA documents focus on the search for solutions to the house design problem, albeit with an underlying pessimism. It becomes apparent from the documents analyzed that architects could never fully agree on the importance of the issue or that the problem could and should be solved by the AIA. Some went as far as to say architects were not even qualified to engage the issue. Many of the documents revealed several of the same themes or codes. A notable exception to this included the earliest documents mentioning small houses reviewed where some of the early codes changed in later documents. The first mention of small houses and their possible relationship to architecture occurred in 1914 in a letter from W.A. Etherton:

\begin{abstract}
There has been a great demand for the working drawings and specification of the little four room house published last spring. These are being prepared and will be published. Just how far to go with this kind of work we have yet to decide, and I have hoped to have the assistance of the Institute in this matter." (Etherton 1914)
\end{abstract}

The immediate response to small house design was an outpouring of enthusiasm wherein architects viewed small house design as their civic duty as architects in a democracy. Everyone deserved a safe and welldesigned house to live in and architects could provide this service.

The Housing Book, which has now been published is meeting with a steady and increasing sale and the committee looks forward with confidence to the ultimate distribution of thousands of copies of this book and the fast and increasing number of men and women who are now ready to cease the superficial methods with philanthropy and charity have approached the problem of the past and adopt, instead, a broad program of constructive character, such as will be in consonance with the ideals of democracy. (Proceedings 1918)

The first resolution with regard to single-family houses made by the American Institute of Architects membership took place in 1918.
Be it Resolved that the Board of Directors request the proper Committee of the Institute to formulate a plan looking toward the development of a better and more harmonious architectural character in small dwelling houses throughout the country; and to recommend the best means for the education or instruction of the public as to what it should have and may get in inexpensive houses. (Proceedings 1918)

At the time of the resolution, there was no appropriate committee to handle the charge. As a result the issue was left to the new incoming Board, and in 1919, the Small House Committee was formed.

In 1922, Edwin H. Brown of Minnesota addressed the AIA convention with the purpose of requesting the AIA's recent endorsement for the Architects Small House Service Bureau (ASHSB). In his address, he refers to the resolution of 1918, the committee formation of 1919, and how the ASHSB meets the needs of the AIA. At the time, the ASHSB reached two million readers a week with its house plans and questions and answer columns in newspapers around the U.S. (Proceedings 1922).

\subsection{9-1934: the endorsement he ASHSB}

The AIA membership did come to an apparent agreement about how to approach the single-family house design problem for a few years when they voted to endorse the Architects Small House Service Bureau. Unfortunately, the original sense of enthusiasm and duty by AIA members on behalf of the single-family house was short lived. By 1924, interest in the ASHSB by AIA members was still minimal. In the meeting minutes from that year, the Small House Committee Report read as follows: "The Board regrets that so few architects have taken a real interest in this valuable movement and that Architectural magazines as well have shown no interest." (Proceedings 1924). At this time fewer than 100 architect members were involved in the ASHSB. While the AIA continued its endorsement for another nine years, the fate of the ASHSB was sealed. By the beginning of the 1930s, the issue of the ASHSB became an openly contentious one. Several members spoke in favor of continued endorsement citing several reasons to participate: working with people on a small house may lead to larger commissions, this type of work was fun for architects, and this type of work could educate people about what an architect could provide. Even those speaking on behalf of the ASHSB within the AIA acknowledged however that there was no money to be made in this type of endeavor and that many local chapters had not been able to participate with the ASHSB as a result. Thus, what had once seemed a civic duty of architects did not appear to be a viable option in practice for many individual architects.

As economic times worsened, architects in the AIA opposed to the ASHSB became more verbal. In 1934, several architects spoke out against continued endorsement of the ASHSB. "The main reason it [the ASHSB] has not succeeded is because architects with initiative and ability to design, refuse to become 
subservient to the stock plan idea." (Meetings minutes 1934). Another architect speaking on the subject reported the following:

Most people buy their small houses already built. The Bureau has not been able to control this class of construction to any degree. The individual who thinks enough of his future home to buy a lot and build his own house should be discouraged from purchasing his stock plan from any source whatever. (Meeting minutes 1934)

This discussion ultimately led to the following resolution by the AIA National Convention attendees:

RESOLVED That the Institute's endorsement of the Architects' Small House Service Bureau be withdrawn as soon as is practicable and fair to do so, but no later than October 1, 1934 and be it further

RESOLVED that the institute continue its efforts to improve the design of the American small house; and that the special committee be continued and urged to make a thorough study of the entire small house problem in all its aspects. (Proceedings 1934)

Following the AIA's revocation of the endorsement, the AIA membership continued to discuss the "small house problem" for several years. The emergent themes from this time period between 1934 and the 1940s were highly consistent. The document review led to many codes associated with problems and outside forces over which architects seemed concerned that they may not have control. These included the need to educate builders, clients, industry, lenders, and the government about architecture and the value of the architect's services, the need to make money in the single-family house market, and the need to come up with a plan to get this type of work. The focus codes developed as a part of this document review are as follows: lack of architects' involvement, warning to architects about their lack of involvement, the pros of working on the small house problem, the need for better small house designs, the solutions found by working with others, the hope for a solution, the need to educate others about architecture, and the analogy to the medical profession. For the next five years, members of the Small House Committee worked diligently to come up with such a plan. These plans were frequently met with member suggestions and complaints. Several members felt that the AIA should educate others about what architects do.

AIA members frequently cited education as the singlemost important thing that the Institute could do with regard to single-family housing design and architectural involvement. They mentioned the need to educate government officials, the public in general, builders, industry and lending agencies. Through education, those they educated were expected to then hire an architect once they knew what an architect provided. The AIA members viewed their value as self-evident and once appreciated, it would lead to work.
In the 1934 Report of the Special Committee on Small Houses, the members communicated the following to the board of the AIA

\begin{abstract}
The Committee believes that the best contribution the Institute can make toward the improvement of small house design is the publicizing of the value of architects' services. Stock plan service offered by commercial agencies is generally incompetent and inadequate. In opposition to such service the Institute should undertake to educate the builders of small houses and those who finance their construction to a realization of the economic value of good design and sound construction; to an understanding that good design involves not only competent planning of the house but also its relation to the lot, to adjacent houses, to the neighborhood, and the landscape treatment. (Report to the Special Committee, no date)
\end{abstract}

The 1938 Report of the Sub-Committee on the Small House Problem recommends: "Let's spend an equal amount of effort and money to educate the public in appreciation of architecture." Dalzell, the author and chair of the committee at the time, provides several means by which this can be accomplished including Architecture Appreciation Courses in all centers of adult education, architecture appreciation in high school curricula, cooperative advertising with manufacturers, taking a greater interest in architectural education at the college level and increasing licensure requirements for architects (Report 1938).

Interestingly, even when architects were successful at educating others of their value, they did not necessarily gain market share as a result. The May 1935 Report of the Committee on Small Houses, demonstrated this result in the following "...the officials of the Federal Housing Administration are convinced of the value and desirability of architectural advice and service for those who finance home building under the F.H.A. guarantee, but that they cannot require such service." (Report 1935). In other words, some AIA members realized that even with education, they were unable to claim a monopoly on design services.

A particularly poignant example of a failure to educate was noted in remarks made by McCornack:

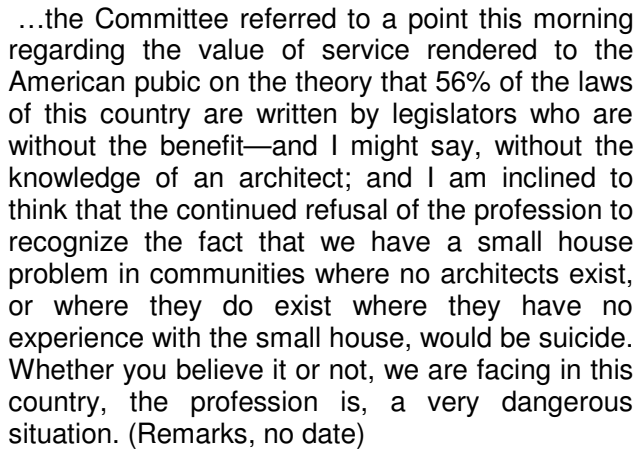

While acknowledging the need for architects to take the small house problem seriously, McCornack also points out that the majority of laws being written were 
composed without a knowledge of an architect's role in the building process. This failure to educate the legislators had a direct correlation to the ultimate failure of architects to create and maintain a monopoly over building design services. McCornack further warns AIA members " 12,000 architects cannot afford to sit idly by and see the great mass of the American people continue without proper service and without knowledge of what the profession can do for them." (Remarks, no date). He continues with an example of government regulation of the profession:

\begin{abstract}
We are facing, also, this situation-that government agencies are taking away from the profession the right to supervise, and when you realize the definition of an architect, that he is a 'master builder', and when you take away from him the experience of putting his plans into materials, you simply take away the life of architecture. (Remarks, no date)
\end{abstract}

As laws and building codes were put in place across the U.S., some architects realized their roles were being controlled through legislation that came without an understanding of what an architect did. Powerful lobbies on behalf of builders, engineers, and corporations argued for their rights to provide design services on par with architects and ultimately succeeded in convincing lawmakers that this was true.

As a relatively new profession, the AIA membership made several references to the medical profession as a model for educating the public and as a profession that was well understood. These AIA members felt that if they followed this model, they too would be a valid profession in the eyes of the general public. An example of such a reference occurs in a letter from $\mathrm{W}$. R. McCornack, the Chairman of the Housing Committee at the time to Albert Mayer of New York City: "I feel that the first duty of the profession is to the building public and that we must solve the problem of extending architectural service to all small home builders in America. The medical profession is finding a way to give medical attention to most of our people today." (McCornack 1936).

Unfortunately for the architecture profession, few codes related to how to accomplish these goals. There were several instances of disagreement and, in some cases, polarization of beliefs as to whether architects should produce plans for ordinary single-family houses. An example of a typical negative comment by a committee member is as follows: "If architects wish to enter the small house field, they should learn something about housing. Nine tenths of the Architects are decidedly ignorant and unqualified." (Document 1938). This animosity led, in some instances, to minority reports without full committee support as well as the final dissolution of the Small House Committee that had attempted to address the issues for nearly thirty years. Throughout the documents, multiple members of the AlA discussed the lack of architectural involvement in single-family house design. Among the reasons for this were apathy, a lack of money to be made, a preference for larger and more public commissions, and that builders already had most of this market in hand. A typical example can be found in the 1934 Special Committee on Small Houses Report: "The Committee now reports its inability to devise a practical method of distributing the plans of the Bureau [ASHSB] only to and through qualified architects for the following reasons, some of which will be recognized as having been advanced by the former Committee..." (Report, 1934). The reasons listed included an inability to define what a qualified architect was, not enough members of the Bureau, impossibility of competing with existing stock plan services, and an inability to make any money doing this type of work.

Another example of this occurs in a memorandum for all the members of the committee on housing dated December 9, 1935 from R. H. Shreve, Chairman of the Committee on Housing. "....in other words, failure up to this time to get Architects into the field of the Small House is thought to be due to the Architects themselves rather than to any lack of opportunity." It becomes clear that some architects in the AIA were struggling with wanting to change the situation yet not having the means or knowledge of how to go about it. Those vocal members who did not want to participate in the first place further complicated the issue, as demonstrated in dissenting views contained within the April 1939 Sub-Committee Report.

Frankly, I cannot see what the furor is about. Good small house plans are published in the professional home building magazines. These plans are available from architects who design them. If supervision is required in the localities where there are no architects let it be done by one who would do it under the Home Loan Bank plans. (Report 1938)

A much more blatant sentiment is expressed in an opinion solicited by the Small House Committee for the same report "I am unalterably opposed to our Committee endorsing any stock plan service, or any other half-way service. If it does, I will submit a minority report at the Convention." (Report 1938).

Other members of the AIA went so far as to warn architects about their lack of concern over the small house problem. One such warning was found in a memo to each chapter president dated March 8, 1937. "Unless some action is taken by architects, they will find themselves gradually being eliminated from the home building field and supplanted by plan service departments in government agencies, or by industrial or financial groups organized to supply plans." (AIA document 1937). This memo continues with a section entitled "Importance to the field" and one enumerating the reasons why architects should be involved in house design. The memo concludes with a statement that describes the results of ignoring the small house problem.

If the architects do nothing then the consequences are obvious and disastrous. The trend is towards group housing, and if architects continue to ignore the single house and its owner, who is too often the victim of unregulated agencies operating on a 
basis of self-interest, the architects will be forgotten when group housing developments come. We spend a lot of time tying to eliminate government architectural agencies after they are created. This affords us an opportunity to prevent the formation of any more. (AIA Document 1937)

This memo highlights the situation at the time where no one was protecting the consumer in the house building market. This was true in 1937 and remains predominantly the case today.

In another instance, Kenneth Dalzell, Chairman of the Sub-Committee on the Small House Problem wrote the following in April 1938: "It is time for the architects of this country to wake up, or we will all be practicing architecture at draughtsmen's (sic) wages for a lot of illiterate speculators with whom the public seems to prefer to do business." (Report 1938).

The primary benefit that architects voiced in support of participating in the small house market repeatedly cited for working on single-family house design was that it provided a good opportunity for young architects first entering the field. It was also seen as a way to provide work in offices during slow times, particularly in the early 1930s. This is stated clearly in a report of the Small House Committee:

The Committee believes that a plan can be worked out which will start the young architects in this country on their careers and may lead them into smaller communities where there are opportunities for them. The Committee also calls attention to the fact that many architects starting in the small house field gradually broaden their practice into other types of work. (McCornack 1938)

Architects routinely spoke of the need for better design in single-family house design. In a memorandum for the Members of the Committee of Housing, R. H. Shreve summarizes this perceived need: "Improve the standards of construction which they [the Government] believe will be accomplished by the engagement of competent architectural service..." (Memorandum 1935). Architects also equated their own services with the solution to this need. Other specific needs which architects spoke about at annual conventions included the need for plan sets in rural locations where there were no architects, the need for architects to provide drawings because stock plan sets were incomplete, the need in general for architects, the need for an economic solution to the issue by which architects could make money, and the need for better housing.

Less clear from the documents were any solutions that could be provided by architects. In fact, most proposed solutions relied on someone else's cooperation with architects. For example, working with government officials to make them want to hire architects was seen as the solution for better housing under government programs. Architects also proposed that they work with lending agencies, again, so that architects would be required for single-family houses designs in order to get a loan. These objectives are included in a draft report of the Committee on Housing of the AIA:
The first step accomplished in the direction of better service in this field has been to establish cooperation between the Federal Housing Administration, the Federal Home Loan Bank Board, the Owners' Loan Corporation, and The Institute, in beginning the study for a program or service to the small house owner on a basis satisfactory to the profession and within the scope of sound business procedure and the standards of our practice...It is quite obvious that plans, specifications, and supervision will be provided in some degree for the great mass of prospective house builders in this country by some agency, either in the governmental bureaus or outside of them, or by the architectural profession. (Draft Report 1937)

Ultimately, these efforts proved unsuccessful and the federal programs would not make architectural services a required component of their individual house design and lending programs.

Almost yearly during this period, some architects would express hope that a solution could be discovered to improve single-family house design in the U.S. While there was a great deal of discussion over the need for and the hope of a solution, less discussion focused on actual solutions beyond the ones mentioned above. Combined with the hope for a solution was frustration over disagreements about a solution. McCornack-who had headed the Small House Committee-- expressed this in a letter to the Executive Committee of the AIA written in 1939: "It is to be hoped that the program, slowly taking form, will end for all time the controversy over the small houses program." (McCornack 1939).

Throughout the AIA documents, there is recognition that architects are not designing the majority of singlefamily houses and that speculative builders were responsible for most houses. A survey conducted by the Executive Committee of the AIA and sent to all State Chapter Presidents in 1938 revealed that perhaps $5 \%$ of all houses were designed by architects and that local builders were using stock plans and interpreting them without the benefit of architectural services. Furthermore, it was estimated that $90 \%$ of all houses were being built by speculative builders using stock plans (Survey results 1938).

\section{CONCLUSION}

Thus the major themes identified in the documents demonstrate the complex issues confronting the architecture profession as it related to single-family house design: the need to educate an ignorant public which included clients, the government, lenders, and builders; the polarization between those who believed architects could engage in house plan set design and those who adamantly opposed this as suitable architecture; and finally the recognition that singlefamily house design was already far outside the reach of architects even in the early twentieth century. Underlying these conflicts was a difference of belief between architects from the northeast and architects from the Midwest about the value of plan books services to the public. Midwestern architects were happy to contribute to better-designed housing stock 
through publishing plans that could be distributed in plan books. This idea was opposed by vocal architects from the northeast from the very beginning and ultimately their view won out.

\section{ACKNOWLEDGMENT}

Portions of the AIA documents were reproduced here thanks to the AIA archivist, Nancy Hadley.

\section{REFERENCES}

Dalzell, K. 1938, "Report of the Sub-Committee of the Small House Problem of Committee on Housing of the American Institute of Architects," AIA Archives, AIA Headquarters, Washington D.C.

Schrenk, L., 1988. "The Impact of the Architects Small House Service Bureau on Early Twentieth Century Domestic Architecture" Master's Thesis, University of Virginia, Charlottesville.

AIA Document, not date. "Report of the Special Committee on Small Houses," AIA Archives, AIA Headquarters, Washington D.C.

AIA Document, March 8, 1937. AIA Archives, AIA Headquarters, Washington D.C.

AIA Document, April 29, 1937. "Draft of Report of Committee on Housing AIA," AIA Archives, AIA Headquarters, Washington D.C.

AIA Document, no date. "Remarks of Mr. McCornack, Wednesday Morning Session," AIA Archives, AIA Headquarters, Washington D.C.

AIA Documents, September 24, 1936. Letter from W. R. McCornack, Chairman, Housing AlA to Mr. Albert Mayer, AIA Archives, AIA Headquarters, Washington D.C .
AIA Document, November 17, 1938. "Survey responses," AIA Archives, AIA Headquarters, Washington D.C.

AIA Document, December 9, 1935. "Memorandum for Members of the Committee on Housing," AlA Archives, AIA Headquarters, Washington D.C

AIA Document, 1934, "Report of the Special Committee on Small Houses," AIA Archives, AIA Headquarters, Washington D.C.

AIA Document, May 21, 1935. "Report of the Committee of the Small House," AIA Archives, AIA Headquarters, Washington D.C.

AIA Document, April 14, 1938. "Report of the SubCommittee on the Small House Problem of the Committee on Housing of the American Institute of Architects," AIA Archives, AIA Headquarters, Washington D.C

AIA Meeting Minutes, 1934. AIA Archives, AIA Headquarters, Washington D.C.

McCornack, W., April 2, 1938. Letter to AIA Executive Committee, "Report of the Committee on Housing," AIA Archives, AIA Headquarters, Washington D.C.

Proceedings of the $57^{\text {th }}$ Convention, 1924. AIA Archives, AIA Headquarters, Washington D.C.

Woods, M, 1999. From Craft to Profession: The Practice of Architecture in Nineteenth Century America, University of California Press: Berkeley. 